\title{
Anemia in pregnancy in Western Jamaica
}

International Journal of Women's Health

8 June 2017

Number of times this article has been viewed

\section{Saidah Wright ${ }^{1}$ \\ Dominique Earland' \\ Swati Sakhuja' \\ Anna Junkins' \\ Sarah Franklin' \\ Luz Padilla' \\ Maung Aung ${ }^{2}$ \\ Pauline E Jolly'}

'Department of Epidemiology, School of Public Health, University of Alabama at Birmingham, Birmingham, AL, USA; ${ }^{2}$ Western Region Health Authority, Cornwall Regional Hospital, Ministry of Health, Montego Bay, Jamaica
Correspondence: Pauline E Jolly

Department of Epidemiology, School of Public Health, University of Alabama at Birmingham, Ryals Building, Room 217, Birmingham, AL 35294-0022, USA

$\mathrm{Tel}+\mathrm{I} 2059341823$

Fax+l 2059348665

Email jollyp@uab.edu
Background: Anemia is one of the most prevalent problems in pregnancy. In 2011, 29.9\% of all pregnant women in Jamaica were diagnosed with anemia.

Objective: The objective of this study was to determine the prevalence and predictors of anemia in pregnancy in Western Jamaica.

Methods: A cross-sectional study was conducted among 293 mothers attending post-natal clinics in Western Jamaica. A questionnaire was administered to the mothers, and an abstraction form was used to collect clinical data from the mothers' records.

Results: The prevalence of anemia among the women was 37.6\%. Younger mothers (aged 18-24 years) were more likely to be anemic compared to those $\geq 35$ years (odds ratio [OR]: 3.44, 95\% CI: 1.07-11.06). Mothers who reported not always washing their hands after using the toilet were almost 10 times more likely to be anemic (OR: 9.7, 95\% CI: 1.72-54.78) compared to those who reported always washing their hands. Mothers who attended a public facility for antenatal care were 2.3 times more likely to be anemic (OR: $2.31,95 \% \mathrm{CI}: 1.03-5.18$ ) compared to those who obtained care at a private facility, and mothers who reported being told that they were anemic by a health care provider (HCP) were almost six times more likely to be anemic compared with those who were not told (OR: 5.58, 95\% CI: 1.73-17.93).

Conclusion: The results of the study indicate that early identification and treatment of anemia, especially among younger pregnant women, should be a priority. HCP should ensure that women understand the need to be cured of their anemia and to adhere to preventive hygienic practices.

Keywords: predictors of anemia, hygienic practices, ANC facilities, Healthcare Providers' communication

\section{Introduction}

Anemia in pregnancy affects nearly half of all pregnant women worldwide and is prevalent in developing countries. ${ }^{1}$ Anemia in pregnancy is not only a risk factor of maternal mortality ${ }^{2}$ but is also harmful for the fetus due to increased risk of adverse birth outcomes such as intrauterine growth retardation, prematurity, and low birth weight (LBW). ${ }^{2,3}$ The prevalence of anemia in pregnancy is of special concern in Jamaica where $29.9 \%$ of pregnant mothers were anemic in $2011 .{ }^{4}$

Clinically, anemia is any hemoglobin $(\mathrm{Hb})$ level $<10.5 \mathrm{~g} / \mathrm{dL}$ regardless of age; however, the World Health Organization (WHO) recommends maintaining $\mathrm{Hb}$ levels $\geq 11.0 \mathrm{~g} / \mathrm{dL}$ during pregnancy. ${ }^{5}$ Anemia in pregnancy develops when physiological changes reduce $\mathrm{Hb}$ concentrations. ${ }^{2}$ These changes are mainly a result of nutritional deficiencies of which iron deficiency is the most common cause. Iron deficiency is the major cause for anemia in pregnant women, accounting for $\sim 75 \%$ of all pregnancy anemia. ${ }^{3}$

The main risk factors for iron deficiency include low intake of iron and poor absorption of iron from diets high in phytate or phenolic compounds. ${ }^{6}$ Evidence also 
suggests that iron deficiency in the body may be precipitated as a result of other nutritional deficiencies. Inadequate intake of vitamin D is associated with an increased risk for iron deficiency, suggesting that overlapping metabolic pathways may also be responsible for anemia in pregnancy. ${ }^{7}$ Vitamin B6 is also a contributing factor to iron deficiency anemia (IDA) as it is believed that vitamin B6 is an essential component for heme synthesis and the use of iron in erythrocyte production. ${ }^{8}$ Other nutritional deficiencies impact the production of erythrocytes, including deficiencies of folic acid and vitamin B12. ${ }^{9}$ Previous medical conditions such as inborn red blood cell disorders can also increase the risk for developing anemia in pregnancy. ${ }^{3}$

In addition, parasitic helminth infections (hookworm and Trichuris) and bacterial infections can contribute to anemia. ${ }^{10-13}$ Intestinal helminth infections can cause IDA, and these infections are present in Jamaica. ${ }^{10-12}$ Helicobacter pylori infection has also been shown to be associated with IDA. ${ }^{13}$ A study that examined the effects of $H$. pylori on different aspects of health, including IDA in 24 patients, showed that $91.7 \%$ of the patients recovered from their IDA after their $H$. pylori infection was cured. ${ }^{13}$

Anemia in pregnancy can be exacerbated by various conditions, including uterine or placental bleeding, gastrointestinal bleeding, and peripartum blood loss. ${ }^{3}$ The many factors that contribute to anemia during pregnancy vary greatly depending on dietary practice, geographical location, and weather or season. ${ }^{14}$

The four parishes that are provided with health care under the Western Regional Health Authority (WRHA) of Jamaica are Saint James, Westmoreland, Trelawny, and Hanover. The WRHA has a network of four hospitals (one in each parish) and 84 health centers strategically positioned throughout the region. ${ }^{15} \mathrm{Hb}$ levels of pregnant women are usually measured at the antenatal clinics during their first prenatal visit. ${ }^{16}$ If a pregnant woman is found to be anemic, a referral is made to the medical doctor, the high-risk clinic, and a nutritionist.

There are several treatment options for anemia in pregnancy, the most common being oral and intravenous iron methods. Education and awareness about anemia have increased in recent decades, and the World Health Assembly has developed an action plan with a commitment to reduce the prevalence of anemia by $50 \%$ among women of reproductive age by $2025 .{ }^{17}$

Jamaica has a high incidence of adverse birth outcomes. ${ }^{18}$ Antepartum hemorrhage is the most important risk factor for fetal death in Jamaica. Congenital malformations caused 6\% of fetal deaths in $1986 .{ }^{19}$ The stillbirth rate in Jamaica declined by $15 \%$ between 1995 and 2005, but still remains high at
12.51/1,000 births. ${ }^{19,20}$ LBW infants account for 8.1/100,000 deaths, and in 2009, 12.1\% of newborns had LBW. Although Jamaica is considered an upper middle-income country with a regional health care system, ${ }^{17}$ the country has several health care constraints that affect timely access to the maternal health care system. For example, $50 \%$ of midwifery positions in both primary and secondary care facilities are vacant. This research study was conducted to determine the prevalence and predictors of anemia among pregnant women attending clinics in the four parishes under the WRHA and to provide data that can be used to design interventions to lower the incidence of anemia in pregnancy in the region.

\section{Methods}

\section{Study design and participant recruitment}

A cross-sectional study was conducted among 293 women attending post-natal care clinics in the four parishes under the WRHA. Public Health nurses told potential participants about the study and asked if they would like to participate. Interested women were introduced to the research staff for further information on the study and to answer any questions from the potential participants. Informed consent was obtained from all of the women who volunteered to participate. Data were collected using an investigator-administered questionnaire to gather information on age, education, employment status, income, residence, personal hygiene, patient compliance to care, and nutrition. The study was approved by the institutional review board at the University of Alabama at Birmingham, and the Western Regional Health Authority of the Jamaican Ministry of Health $(\mathrm{MOH})$. Anemia was categorized based on the WHO's recommendations of $\mathrm{Hb}<11 \mathrm{~g} / \mathrm{dL} .^{5}$ The $\mathrm{Hb}$ test is done at the first visit of the women to the antenatal clinic. The $\mathrm{MOH}$ encourages women to visit the antenatal care (ANC) clinic in their first trimester of pregnancy; however, the trend is that mothers tend to come for their first visit in their second trimester.

A clinical data abstraction form was used to obtain obstetric information (gestational age as assessed at the first ANC visit and all illnesses, including chronic or infectious) and treatments during pregnancy from the women's ANC visit records. Delivery data were collected for the infants (newborn's state [live or stillbirth], sex, weight, length, and Apgar score).

\section{Data analysis}

Descriptive statistics were used to examine the differences between sociodemographic characteristics, hygienic practices, ANC visits, clinical treatment and education, and obstetric history of the women and their anemia status (based 
on $\mathrm{Hb}$ levels $<11 \mathrm{~g} / \mathrm{dL}$ or $\geq 11 \mathrm{~g} / \mathrm{dL}$ ). The chi-square test was used for categorical variables, and Fisher's exact test was used for categorical variables with low cell counts (predicted value $\leq 0.05$ ). All analyses were conducted using SAS 9.4 (SAS Institute Inc., Cary, NC, USA). Additionally, multivariable logistic regression models were created to examine the relationship between anemia status and socio-demographic and hygienic characteristics of the women. Furthermore, a logistic regression model was used to analyze the associations adjusted for variables with $P$-values $\leq 0.05$, which included age, washing hands after bathroom use, wearing shoes outside daily, place of ANC visits, and diagnosis of anemia by health care provider.

\section{Results}

Of the 293 mothers who participated in the study, 197 had records of $\mathrm{Hb}$ levels to determine their anemia status and were included in the analysis. Majority of the women (62\%) were from the parish of Saint James, 15\% were from Westmoreland, 12\% from Hanover, and 10\% from Trelawny (Table 1 ). Over $37 \%$ of women satisfied the criteria of being anemic based on the WHO recommendations. Most women (66.2\%) were mildly anemic ( $\mathrm{Hb} 10-10.9 \mathrm{~g} / \mathrm{dL}), 32.4 \%$ were moderately anemic (Hb 7.0-9.9 g/dL), and 1.4\% were severely anemic $(\mathrm{Hb}<7.0 \mathrm{~g} / \mathrm{dL})$.

The proportions of women with anemia were significantly higher in the 18-24 years and 25-29 years age groups compared to non-anemic mothers (48.6\% vs 33.3\% and 33.8\% vs $30.1 \%$, respectively; $P=0.0342$ ). A majority of both anemic and non-anemic mothers had some/completed secondary education, and most earned the minimum weekly income of $\leq \mathrm{J} \$ 9,200$. The average household size was four or more people for both groups of women.

A majority of mothers had access to a toilet facility inside their homes, but this was not significantly associated with an anemia diagnosis (Table 2). With regard to wearing shoes outdoors on a daily basis, $70 \%$ of anemic mothers reported always wearing shoes compared to $82 \%$ of non-anemic mothers, but this association was also not significant $(P=0.0532)$. Additionally, maintaining personal hygiene by always washing hands before eating was almost equally reported by the two groups, but always washing hands after using the toilet was significantly less reported by anemic mothers compared to non-anemic mothers $(89.1 \%$ vs $98.4 \%, P=0.0045)$.

Indicators of ANC compliance, such as availability of transportation to the clinic, regular attendance at the clinic, receiving iron and folic acid tablets, and receiving education regarding food to be consumed in pregnancy,
Table I Sociodemographic characteristics of the study population

\begin{tabular}{|c|c|c|c|}
\hline Variables & $\begin{array}{l}\text { Anemia, } \\
74(37.6 \%), \\
\text { n (\%) }\end{array}$ & $\begin{array}{l}\text { No anemia, } \\
\text { I } 23(62.4 \%) \text {, } \\
\text { n (\%) }\end{array}$ & $P$-value* \\
\hline Parish & & & 0.9065 \\
\hline Saint James & $44(60.3)$ & 77 (63.I) & \\
\hline Westmoreland & II (I5.I) & $19(15.6)$ & \\
\hline Hanover & $9(12.3)$ & $15(12.3)$ & \\
\hline Trelawny & $9(12.3)$ & II (9.0) & \\
\hline Age (years) & & & 0.0342 \\
\hline $18-24$ & 36 (48.7) & $4 \mid(33.3)$ & \\
\hline $25-29$ & $25(33.8)$ & $37(30.1)$ & \\
\hline $30-34$ & $7(9.5)$ & $25(20.3)$ & \\
\hline$\geq 35$ & $6(8.1)$ & $20(16.3)$ & \\
\hline Education & & & 0.2729 \\
\hline Primary or less & $4(5.5)$ & $5(4.1)$ & \\
\hline $\begin{array}{l}\text { Some secondary or } \\
\text { completed secondary }\end{array}$ & $43(58.9)$ & $58(47.5)$ & \\
\hline College & $14(19.2)$ & $25(20.5)$ & \\
\hline Other & $12(16.4)$ & 34 (27.9) & \\
\hline Religious affiliation & & & 0.8279 \\
\hline Christian & $56(75.7)$ & $96(78.3)$ & \\
\hline Rastafarian & $0(0.0)$ & I (0.8) & \\
\hline None & $18(24.3)$ & $26(2 I .1)$ & \\
\hline Marital status & & & 0.6455 \\
\hline Never married & 38 (5I.4) & $59(48.0)$ & \\
\hline Ever married/common law & $36(48.7)$ & $64(52.0)$ & \\
\hline Occupation & & & 0.2964 \\
\hline Professional & $3(10.3)$ & $10(14.5)$ & \\
\hline Skilled & $16(55.2)$ & $26(37.7)$ & \\
\hline Clerical & $4(13.8)$ & $7(10.1)$ & \\
\hline Other & $6(20.7)$ & $26(37.7)$ & \\
\hline Income & & & 0.1036 \\
\hline$\leq \mathrm{J} \$ 9,200$ & $15(53.6)$ & $22(31.4)$ & \\
\hline$<\mathbb{J} \$ 5,200$ & $3(10.7)$ & $19(27.1)$ & \\
\hline$>\mid \$ 18,200$ & $8(28.6)$ & 18 (25.7) & \\
\hline None or $\mathrm{n} / \mathrm{a}$ & $2(7.1)$ & II (I5.7) & \\
\hline Number in household & & & 0.1922 \\
\hline $\mathrm{I}-3$ & $19(25.7)$ & $22(17.9)$ & \\
\hline$\geq 4$ & $55(74.3)$ & $101(82.1)$ & \\
\hline
\end{tabular}

Notes: $*$ Chi-square test and Fisher's exact test were used. Numbers may not add up to the total number due to missing responses. Bold indicates significant at $P<0.05$. Abbreviation: $\mathrm{n} / \mathrm{a}$, not applicable.

Table 2 Available toilet facility in home and hygienic practices

\begin{tabular}{|c|c|c|c|}
\hline Variable & $\begin{array}{l}\text { Anemia, } \\
74(37.56 \%), \\
\text { n (\%) }\end{array}$ & $\begin{array}{l}\text { No anemia, } \\
\text { I } 23 \text { (62.44\%), } \\
\text { n (\%) }\end{array}$ & $P$-value* \\
\hline \multicolumn{3}{|c|}{ Toilet facilities inside home } & 0.5709 \\
\hline No & $6(8.1)$ & $13(10.6)$ & \\
\hline Yes & $68(91.9)$ & $110(89.4)$ & \\
\hline \multicolumn{3}{|c|}{ Wear shoes outside daily } & 0.0532 \\
\hline Always & $52(70.3)$ & $101(82.1)$ & \\
\hline Often/sometimes & $22(29.7)$ & $22(17.9)$ & \\
\hline \multicolumn{3}{|c|}{ Wash hands before eating } & 0.8693 \\
\hline Always & $43(58.1)$ & $70(56.9)$ & \\
\hline Often/sometimes & 31 (4I.9) & $53(43.1)$ & \\
\hline \multicolumn{3}{|c|}{ Wash hands after using bathroom } & 0.0045 \\
\hline Always & $66(89.2)$ & I2I (98.4) & \\
\hline Often/sometimes & $8(10.8)$ & $2(1.7)$ & \\
\hline
\end{tabular}

Notes: *Chi-square test and Fisher's exact test were used. Numbers may not add up to the total number due to missing responses. Bold indicates significant at $P<0.05$. 
were not significantly associated with anemia among the mothers (Table 3). A significantly higher proportion of anemic compared to non-anemic mothers reported attending a public facility for their ANC care $(83.8 \%$ [public] vs $70.5 \%$ [private]; $P=0.0359$ ).

When obstetric history of the women (any pregnancy) was examined according to anemia status, no differences were found for the number of births and adverse birth outcomes between the two groups (Table 4). When the most recent pregnancy was considered, there was a significant difference in the diagnosis of anemia by a health care provider (HCP) between the groups $(P=0.0029)$. Only $\sim 16 \%$ of

Table 3 ANC attendance and education about anemia and nutrition

\begin{tabular}{|c|c|c|c|}
\hline Variables & $\begin{array}{l}\text { Anemia, } \\
74(37.56 \%), \\
\text { n (\%) }\end{array}$ & $\begin{array}{l}\text { No anemia, } \\
\text { I } 23(62.44 \%), \\
\text { n (\%) }\end{array}$ & P-value* \\
\hline \multicolumn{3}{|c|}{ Type of transportation to ANC appointments } & 0.8086 \\
\hline Drive & $21(28.8)$ & $41(33.3)$ & \\
\hline Walk & $9(12.3)$ & II (8.9) & \\
\hline Public transportation & $38(52.1)$ & $61(49.6)$ & \\
\hline All of the above & $5(6.9)$ & $10(8.1)$ & \\
\hline \multicolumn{3}{|c|}{ Attendance at all scheduled appointments } & 1.0000 \\
\hline No & $3(4.1)$ & $6(4.9)$ & \\
\hline Yes & $70(95.9)$ & $117(95.1)$ & \\
\hline \multicolumn{3}{|c|}{ Number of appointments missed } & 0.3501 \\
\hline $\mathrm{I}-2$ & $18(24.7)$ & $38(30.9)$ & \\
\hline $3-4$ & $55(75.3)$ & $85(69.1)$ & \\
\hline Received iron tablets & & & 1.0000 \\
\hline No & $\mathrm{I}(\mathrm{I} .4)$ & $3(2.4)$ & \\
\hline Yes & $73(98.7)$ & $120(97.6)$ & \\
\hline \multicolumn{3}{|c|}{ Received folic acid tablets } & 0.1164 \\
\hline No & $15(20.6)$ & $15(12.2)$ & \\
\hline Yes & $58(79.5)$ & $108(87.8)$ & \\
\hline \multicolumn{3}{|l|}{ Type of ANC facility } & 0.0359 \\
\hline Public facility & $62(83.8)$ & $86(70.5)$ & \\
\hline Private facility & $12(16.2)$ & $36(29.5)$ & \\
\hline \multicolumn{3}{|c|}{ Received education about anemia prevention in pregnancy } & 0.4111 \\
\hline No & $18(25.7)$ & $37(31.4)$ & \\
\hline Yes & $52(74.3)$ & $81(68.6)$ & \\
\hline \multicolumn{3}{|c|}{ Received education about foods that prevent anemia } & 0.9316 \\
\hline No & $18(24.7)$ & $30(25.2)$ & \\
\hline Yes & $55(75.3)$ & $89(74.8)$ & \\
\hline \multicolumn{3}{|c|}{ Received education about foods that prevent iron } & 0.5230 \\
\hline \multicolumn{3}{|c|}{ absorption } & \\
\hline No & $21(29.2)$ & $40(33.6)$ & \\
\hline Yes & $51(70.8)$ & $79(66.4)$ & \\
\hline \multicolumn{3}{|c|}{$\begin{array}{l}\text { Received counseling about proper nutrition during } \\
\text { pregnancy }\end{array}$} & 0.8618 \\
\hline No & $6(8.2)$ & II (8.9) & \\
\hline Yes & $67(91.8)$ & $112(91.1)$ & \\
\hline
\end{tabular}

Notes: *Chi-square test and Fisher's exact test were used. Numbers may not add up to the total number due to missing responses. Bold indicates significant at $P<0.05$.

Abbreviation: ANC, antenatal care.
Table 4 Obstetric information for any pregnancy and for the most recent pregnancy

\begin{tabular}{|c|c|c|c|}
\hline Variable & $\begin{array}{l}\text { Anemia, } \\
74(37.56 \%), \\
\text { n (\%) }\end{array}$ & $\begin{array}{l}\text { No anemia, } \\
\text { I } 23(62.44 \%), \\
\text { n (\%) }\end{array}$ & $P$-value* \\
\hline \multicolumn{4}{|l|}{ Any pregnancy } \\
\hline \multicolumn{2}{|c|}{ Number of times given birth } & & 0.5801 \\
\hline Never & $25(34.7)$ & $43(35.3)$ & \\
\hline Once & $25(34.7)$ & $42(34.4)$ & \\
\hline Twice & $17(23.6)$ & $22(18.0)$ & \\
\hline Three times or more & $5(6.9)$ & $15(12.3)$ & \\
\hline Pre-term delivery & & & 0.9340 \\
\hline No & $59(80.8)$ & $100(81.3)$ & \\
\hline Yes & $14(19.2)$ & $23(18.7)$ & \\
\hline LBW delivery & & & 0.2823 \\
\hline No & $62(86.1)$ & II 2 (9I.I) & \\
\hline Yes & $10(13.9)$ & II (8.9) & \\
\hline Induced abortion in past & & & 0.5763 \\
\hline No & $66(90.4)$ & $108(87.8)$ & \\
\hline Yes & $7(9.6)$ & $15(12.2)$ & \\
\hline Still births & & & 0.3056 \\
\hline No & $64(90.4)$ & $116(94.3)$ & \\
\hline Yes & $7(9.6)$ & $7(5.7)$ & \\
\hline Miscarriage & & & 0.3501 \\
\hline No & $55(75.3)$ & $85(69.1)$ & \\
\hline Yes & I8 (24.7) & $38(30.9)$ & \\
\hline Pregnancy complications & & & 0.8213 \\
\hline No & $59(80.8)$ & I0I (82.I) & \\
\hline Yes & $14(19.2)$ & $22(17.9)$ & \\
\hline Birthing complications & & & 0.5464 \\
\hline No & $64(87.7)$ & $104(84.6)$ & \\
\hline Yes & $9(12.3)$ & $19(15.5)$ & \\
\hline \multicolumn{4}{|l|}{ Most recent pregnancy } \\
\hline First child ever & & & 0.6610 \\
\hline No & $45(60.8)$ & 78 (63.9) & \\
\hline Yes & $29(39.2)$ & $44(36.1)$ & \\
\hline \multicolumn{2}{|c|}{ Told of anemia status by HCP } & & 0.0029 \\
\hline No & $61(83.6)$ & 118 (95.9) & \\
\hline Yes & $12(16.4)$ & $5(4.1)$ & \\
\hline Vaginal bleeding & & & 0.9218 \\
\hline No & $58(79.5)$ & 97 (78.9) & \\
\hline Yes & $15(20.6)$ & $26(21.1)$ & \\
\hline Severe illness & & & 0.6857 \\
\hline No & $62(84.9)$ & $107(87.0)$ & \\
\hline Yes & II (I5.I) & $16(13.0)$ & \\
\hline Pre-eclampsia & & & 0.9890 \\
\hline No & $60(82.2)$ & I0I (82.I) & \\
\hline Yes & $13(17.8)$ & $22(17.9)$ & \\
\hline Emergency care needed & & & 0.6403 \\
\hline Never & $50(67.6)$ & $87(70.7)$ & \\
\hline One or more times & $24(32.4)$ & $36(29.3)$ & \\
\hline \multicolumn{2}{|c|}{ Infant health problem at birth } & & 0.7587 \\
\hline No & $53(84.1)$ & $97(85.8)$ & \\
\hline Yes & $10(15.9)$ & $16(14.2)$ & \\
\hline
\end{tabular}

Notes: *Chi-square test and Fisher's exact test were used. Numbers may not add up to the total number due to missing responses. Bold indicates significant at $P<0.05$. Abbreviations: LBW, low birth weight; HCP, health care provider. 
Table 5 Multivariable logistic regression analysis for factors associated with having anemia in pregnancy

\begin{tabular}{|c|c|c|}
\hline Variables & $\begin{array}{l}\text { Unadjusted OR } \\
(95 \% \mathrm{Cl})\end{array}$ & $\begin{array}{l}\text { Adjusted OR } \\
(95 \% \mathrm{CI})^{\S}\end{array}$ \\
\hline \multicolumn{3}{|l|}{ Age (years) } \\
\hline $18-24$ & $2.93(1.06-8.09)$ & $3.44(1.07-11.06)$ \\
\hline $25-29$ & $2.52(0.79-6.40)$ & $3.18(0.96-10.58)$ \\
\hline $30-34$ & $0.93(0.27-3.22)$ & $1.29(0.32-5.20)$ \\
\hline$\geq 35$ & Ref & \\
\hline \multicolumn{3}{|c|}{ Wash hands after bathroom } \\
\hline Always & Ref & Ref \\
\hline Often/sometimes & $7.33(1.5 I-35.54)$ & $9.70(1.72-54.78)$ \\
\hline \multicolumn{3}{|c|}{ Wear shoes outside daily } \\
\hline Always & Ref & Ref \\
\hline Often/sometimes & $1.94(0.98-3.83)$ & $1.99(0.94-4.19)$ \\
\hline \multicolumn{3}{|l|}{ Type of ANC facility } \\
\hline Public facility & $2.16(1.04-4.49)$ & $2.31(1.03-5.18)$ \\
\hline Private facility & Ref & Ref \\
\hline \multicolumn{3}{|c|}{ Told of anemia by HCP } \\
\hline No & Ref & Ref \\
\hline Yes & $4.64(1.56-13.78)$ & $5.58(1.73-17.93)$ \\
\hline
\end{tabular}

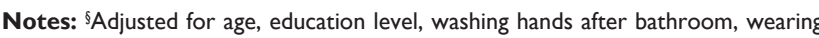
shoes outside daily, place of ANC visits, and diagnosis of anemia by HCP. Bold indicates significant values.

Abbreviations: OR, odds ratio; ANC, antenatal care; HCP, health care provider.

women with anemia (based on the recorded $\mathrm{Hb}$ level in their charts) reported that they were told that they were anemic by their HCPs; the remaining $84 \%$ reported that they were not provided with an anemia diagnosis. Among non-anemic mothers, $4 \%$ reported that they were told they were anemic by their HCPs, although these women had recorded Hb levels ranging from 11.2 to $12.3 \mathrm{~g} / \mathrm{dL}$.

In the unadjusted analysis, anemia was more likely to be present in mothers aged 18-24 years (OR: 2.93, 95\% CI: 1.06-8.09) compared to those $\geq 35$ years, and this association was even stronger in the adjusted analysis (OR: 3.44, 95\% CI: 1.07-11.06; Table 5). Mothers who reported not always washing their hands after using the toilet were almost 10 times more likely to be anemic (OR: 9.7, 95\% CI: 1.72-54.78) compared to those who reported always washing their hands after using the toilet.

The type of facility where the women obtained ANC was also a predictor of anemia status among the women. Women who attended a public facility were 2.3 times more likely to be anemic (OR: 2.31, 95\% CI: 1.03-5.18) compared to those who obtained care at a private facility. In addition, women who reported being told they were anemic by an HCP were almost six times more likely to be anemic compared with those who were not told (OR: 5.58, 95\% CI: 1.73-17.93).

\section{Discussion}

It is clear that anemia continues to be a major health problem for pregnant women in the Western region of Jamaica.
Our data show that the Western Health Region has a higher prevalence of anemia during pregnancy (37.6\%) than the national average (29.9). ${ }^{4}$ Previously, we found an anemia prevalence rate of $34.8 \%$ in a study conducted in one of the Western parishes. ${ }^{21}$ The $29.9 \%$ overall anemia rate for Jamaica is an average of the rates for the 14 parishes in the country. Therefore, it is an average of lower rates in some parishes and higher rates in others. The WHO reported an anemia rate of $40.7 \%$ for Jamaican women aged 13-46.99 years in 2006 and rates of $47.0 \%, 47.9 \%$, and $41.8 \%$ for the South East, North East and Western regions, respectively; a significantly lower rate of $17.9 \%$ was reported for the Southern region. ${ }^{22}$ The reasons for the variation in anemia rates among women in different regions of Jamaica are not immediately apparent but may be related to the level of poverty in the parishes in the different regions. Although the overall poverty rate in Jamaica in 2002 was $19.7 \%$, parishes with the highest incidence of poverty were found in the North East and Western regions of the island, such as Portland, Saint Ann, and Trelawny, with rates of $32.3 \%, 37.0 \%$ and $31.3 \%$, respectively. ${ }^{23}$ In 2012, the prevalence of poverty in Jamaica increased by $2.3 \%$ over the 2010 rate to $19.9 \%$, and poverty rates increased in the two largest parishes of the Western region, namely, Saint James (increase of 2.7\%-11.2\%) and Westmoreland (increase of $8.2 \%-18.9 \%$ ). ${ }^{24}$ Poverty is highly correlated with lack of proper sanitation, and both factors have been linked to increased risks to maternal health. ${ }^{25,26}$ Poverty is also associated with poor nutrition, which can result in anemia.

Steps taken to alleviate the anemia problem are currently incorporated into the antenatal system of care for pregnant women in Jamaica. ${ }^{18}$ Iron tablets are given to all pregnant women by nurses in the Western Health Region antenatal clinics regardless of history of anemia in pregnancy. Folic acid tablets are also given to women who are diagnosed with anemia in pregnancy or who have had a history of anemia in other pregnancies.

The data collected in this study showed that women aged 18-24 years were more than three times more likely to have anemia in pregnancy compared to women $\geq 35$ years of age. A study conducted among pregnant women in Nigeria showed that younger women $(<30$ years) constituted the highest percent of anemia cases $(68.62 \%) .{ }^{27}$ On the contrary, studies conducted in Ethiopia and China observed that the prevalence of anemia was highest among older women ( $\geq 30$ years). ${ }^{28,29}$ The increased risk of anemia among younger women in Jamaica could be due to unplanned pregnancy and suboptimal nutritional status prior to conception. ${ }^{30}$ It is known 
that there is an increased risk for anemia among teenage mothers due to their greater nutritional requirements during growth spurts. ${ }^{30,31}$ The increased risk seen among younger mothers could also be a reflection of the carryover of the teenage risk into young adulthood.

Not always washing hands after using the toilet was found to be a predictor of anemia among the women. Hygienic preventive practices, such as hand washing especially after using the toilet and wearing shoes outdoors, are essential for preventing bacterial and parasitic infections that can cause anemia in pregnancy. Although Jamaica is classified as an upper middle income country and has a regional health care system, the country has struggled with low economic growth for over three decades and is one of the slowest growing developing countries in the world; it had accumulated debt $145 \%$ of gross domestic product (GDP) in 2012. ${ }^{32}$ Improved sanitation and safe piped household water are not available to everyone in Jamaica. Piped water was available for $72.5 \%$ of Jamaican households in 2009; $13.7 \%$ of households collected rainwater and $6.2 \%$ used public standpipes. ${ }^{33}$ Although $86.3 \%$ of people in metropolitan areas had access to piped water, this was true for only $46 \%$ of those in rural areas. ${ }^{33}$ Without readily available piped water, handwashing and other hygienic practices will not be carried out satisfactorily. In 2002, 66.2\% of households in the Western region had access to potable water compared with $86.2 \%$ of households in the South East region and $98.2 \%$ in the Kingston and Saint Andrew metropolitan areas. ${ }^{23}$ With regard to sanitary facilities, $67.6 \%$ of households in Jamaica reported having flush toilets and $32.3 \%$ reported having pit latrines in $2009 .{ }^{33}$ In metropolitan areas outside of Kingston, $75.3 \%$ of households had flush toilets compared with $47.8 \%$ in rural areas. ${ }^{34}$ For the country as a whole, $76 \%$ of toilet facilities were not linked to a sewer system, but this could be as high as $95.1 \%$ in rural areas. ${ }^{34} \mathrm{With}$ high proportions of the population not having improved drinking-water sources and sanitation facilities, poor hygienic practices and transmission of geohelminths and other parasitic infections that promote poor nutrition and anemia are likely to occur.

The main parasites causing blood loss in human beings and leading to direct iron-deficiency anemia include hookworm infection (Necator americanus and Ancylostoma duodenale), whipworm infection (Trichuris trichiura), and schistosomiasis. ${ }^{35,36}$ Although we did not examine helminth infections in the women in the study, helminth infections could be contributing to anemia. ${ }^{10-12}$ Studies conducted in Jamaica show that transmission of geohelminth infections such as T. trichiuria and Ascaris lumbricoides, occurs commonly on the island. ${ }^{10-12}$ A country-wide study on gastrointestinal infections in Jamaica reported infection rates for Trichuris (12.3\%), Ascaris (9.5\%), hookworm (2.2\%), and Strongyloides (0.3\%). ${ }^{12}$ Giardia lamblia (6.3\%) and Entameba coli $(7.7 \%)$ were protozoans that were more commonly found in the study. ${ }^{12}$ The study found higher parasite infection rates in rural compared with urban areas. Another study found infection rates of $42 \%-47 \%$ for Trichuris and $15 \%-37 \%$ for Ascaris among school children in the capital city of Kingston and in rural areas of Jamaica. ${ }^{11}$ A study conducted on anemia and geohelminth infection in primary school children in the rural parishes of Clarendon, Manchester, Saint Ann, and Trelawny (the latter being one of the parishes in the Western region) found that $14.7 \%$ of the children were anemic, $38.3 \%$ were infected with Trichuris, and $19.4 \%$ with Ascaris. ${ }^{10}$ Trichuris infection has been shown to be directly related to anemia among pregnant women and among school children in Jamaica. ${ }^{37,38}$ The mechanisms by which Trichuris infection may cause anemia include ingestion of blood by the parasite, blood loss from parasiteproduced lesions in the intestinal mucosa, and inflammatory responses to the parasitic infection. ${ }^{39}$

Although Ascaris infection is known to influence nutritional status, its impact on anemia is less clear. However, a statistically significant association was found between Ascaris infection and anemia in a study among school children in Nigeria. ${ }^{40,41}$ Anemia was also reported to be resolved when an anemic patient with positive fecal occult blood test and Ascaris infection was treated with antihelminthic medication. ${ }^{42}$ Giardiasis has been shown to cause iron deficiency. ${ }^{43,44}$ One study showed a significant reduction in anemia $(26.5 \%-1.9 \%)$ after treatment of children in Iran for giardiasis. ${ }^{45}$ Examination of parasitic infections in anemic pregnant women should be conducted, and the women should be treated. In addition, hand hygiene should be an integral part of preventive messages given to pregnant women during ANC visits.

The current study found that mothers who reported that an HCP told them they were anemic were almost six times more likely to be anemic. However, the data show that $>80 \%$ of anemic women reported that an HCP did not tell them they were anemic. This indicates that there needs to be better communication between HCPs and the women. Time needs to be taken in the clinic to ensure that the women understand their anemia status, the implications of being anemic, and how the condition can be treated and rectified. Studies have shown that the quality of patient-clinician communication affects the health outcomes of patients. ${ }^{46,47}$ A majority of 
the women (98\%) reported that they were given iron tablets during pregnancy. However, follow-up needs to be conducted to verify adherence to the medication and improvement in the $\mathrm{Hb}$ level within reasonable time. Most importantly, the follow-up information and new $\mathrm{Hb}$ measurement need to be documented in the women's records.

The type of facility women attended for ANC was a significant predictor of anemia status with women who attended a public health care facility being more than two times more likely to be anemic compared with women who attended a private facility. It is likely that the shortage of staff and the abundant demand on public government facilities decrease the time available for HCP to appropriately test, record, and counsel women regarding anemia status. It is also possible that women who can afford to pay to obtain care at a private facility are also more likely to be better educated, have more financial resources, eat better, and have better nutritional status.

We recommend early implementation of interventions addressing anemia in pregnancy, especially targeted at younger women. These could include the use of educational materials, such as videos, pamphlets, posters, and cell phone messages, focused on appropriate nutrition, types of food, need for and benefits of iron and folic acid supplementation, hygienic preventive practices, and compliance with medications and clinic attendance. Women who test positive for anemia at their first antenatal visit or those with a history of anemia should be immediately separated for special treatment and follow-up care. These steps may lead to decrease in anemia among pregnant women in the Western region and elsewhere in Jamaica.

\section{Limitations}

The small sample size and even the lower number of women with $\mathrm{Hb}$ measurements who could be included in the analysis are limitations of this study that should be considered in interpreting the results. Some women declined to participate in the study or did not complete the questionnaire because there was another study being conducted concurrently at the clinics and they did not want to participate in both studies. In addition, some women who agreed to participate could not stay to complete the questionnaire after their long wait to be seen at the clinic. The low number of and marginally significant differences in our results can most likely be attributed to the small sample size used for data analysis. An additional limitation of the study is that several of the factors that have been found to be related to anemia, such as diet and nutritional status prior to conception, anemia before pregnancy, infectious and chronic diseases, and spacing of pregnancies, were not examined.

\section{Conclusion}

Nevertheless, the research identified younger age, not always washing hands after using the toilet, attending a public ANC facility and being told of positive anemia status by a HCP, as significant predictors of anemia among the women. These results indicate that early identification and treatment of anemia, especially among younger pregnant women, should be a priority in antenatal care in Jamaica. There also needs to be better communication between HCPs and the women to ensure that the women understand their anemia status, the adverse health effects for themselves and their unborn babies and how the condition can be treated and corrected. Strict adherence to preventive hygienic practices should also be emphasized by HCPs. The MOH should consider testing pregnant women for intestinal parasites and treating these infections.

\section{Acknowledgments}

We thank the women who participated in the study and the nurses at the health centers who facilitated the study. This study was supported by the Minority Health International Research Training (MHIRT), grant no T37-MD001448, from the National Institute on Minority Health and Health Disparities, National Institutes of Health (NIH), Bethesda, $\mathrm{MD}, \mathrm{USA}$, and the $\mathrm{MOH}$, Jamaica.

\section{Disclosure}

The authors report no conflicts of interest in this work.

\section{References}

1. Viteri FE, Berger J. Importance of pre-pregnancy and pregnancy iron status: can long-term weekly preventive iron and folic acid supplementation achieve desirable and safe status? Nutr Rev. 2005;63(12): 65-76.

2. Brabin BJ, Hakimi M, Pelletier D. An analysis of anemia and pregnancy-related maternal mortality. J Nutr. 2001;131(2S-2): 604S-614S

3. Sifakis S, Pharmakides G. Anemia in pregnancy. Ann N Y Acad Sci. 2006; 900(1):125-136.

4. Stevens GA, Finucane MM, De-Regil LM, et al. Global, regional, and national trends in haemoglobin concentration and prevalence of total and severe anaemia in children and pregnant and non-pregnant women for 1995-2011: a systematic analysis of population-representative data. Lancet Glob Health. 2013;1(1):e16-e25.

5. World Health Organization. Haemoglobin Concentrations for the Diagnosis of Anaemia and Assessment of Severity. World Health Organization; 2011. Available from: http://www.who.int/vmnis/indicators/haemoglobin.pdf. Accessed April 22, 2016.

6. Mclean E, Cogswell M, Egli I, Wojdyla D, Benoist BD. Worldwide prevalence of anaemia, WHO vitamin and mineral nutrition information system, 1993-2005. Public Health Nutr. 2008;12(04):444. 
7. Thomas CE, Guillet R, Queenan RA, et al. Vitamin D status is inversely associated with anemia and serum erythropoietin during pregnancy. Am J Clin Nutr. 2015;102(5):1088-1095.

8. Institute of Medicine (US) Standing Committee on the Scientific Evaluation of Dietary Reference Intakes and its Panel on Folate, Other B Vitamins, and Choline. Dietary Reference Intakes for Thiamin, Riboflavin, Niacin, Vitamin B6, Folate, Vitamin B12, Pantothenic Acid, Biotin, and Choline. Washington (DC): National Academies Press (US); 1998. Available from: https://www.ncbi.nlm.nih.gov/books/NBK114310/. Accessed May 18, 2017.

9. The Reproductive Health Library; World Health Organization [webpage on the Internet]. [Treatments for Iron-Deficiency Anaemia in Pregnancy]; 2008. Available from: https://extranet.who.int/rhl/topics/pregnancy-and-childbirth/medical-problems-during-pregnancy/ anaemia-during-pregnancy/treatments-iron-deficiency-anaemiapregnancy. Accessed April 22, 2016.

10. Hutchinson SE, Powell CA, Walker SP, Chang SM, GranthamMcgregor SM. Nutrition, anaemia, geohelminth infection and school achievement in rural Jamaican primary school children. Eur J Clin Nutr. 1997;51(11):729-735.

11. Wong MS, Simeon DT, Powell CA, Grantham-McGregor SM. Geohelminth infections in school-aged children in Jamaica. West Indian Med J. 1994;43(4):121-122.

12. Rawlins SC, Campbell M, Fox K, Bennett F, Gibbs WN, Greene M. Parasitic infections in young Jamaicans in different ecological zones of the island. Trop Geogr Med. 1991;43(1-2):136-141.

13. Annibale B, Marignani M, Monarca B, et al. Reversal of iron deficiency anemia after Helicobacter pylori eradication in patients with asymptomatic gastritis. Ann Intern Med. 1999;131(9):668.

14. VanderJagt DJ, Brock HS, Melah GS, El-Nafaty AU, Crossey MJ, Glew RH. Nutritional factors associated with anaemia in pregnant women in Northern Nigeria. J Health Popul Nutr. 2007;25(1):75-81.

15. Western Regional Health Authority [webpage on the Internet]. Authority Western Regional Health Authority Profile; 2009. Available from: http://www.wrha.gov.jm/content/wrha_profile.html. Accessed April 22, 2016.

16. Pan American Health Organization [webpage on the Internet]. [Basic Indicator Browser - By Countries and Selected Year]; 2005. Available from: http://ais.paho.org/phip/viz/basicindicatorbrowaser.asp. Accessed April 22, 2016.

17. Lozano R, Naghavi M, Foreman K, et al. Global and regional mortality from 235 causes of death for 20 age groups in 1990 and 2010: a systematic analysis for the global burden of disease study 2010 . Lancet. 2012;380(9859):2095-2128.

18. Pan American Health Organization [webpage on the Internet]. [Jamaica Country Cooperation Strategy 2010-2015]; 2010. Available from: http://iris.paho.org/xmlui/handle/123456789/5612. Accessed April 22, 2016.

19. Bale JR, Stoll BJ, Lucas AO, editors. Improving Birth Outcomes: Meeting the Challenge in the Developing World. Washington, DC: National Academies Press; 2003.

20. ChartsBin Statistics Collector Team [webpage on the Internet]. [Current Worldwide Stillbirth Rate (Per 1000 Births)]. ChartsBin.com; 2011. Available from: http://chartsbin.com/view/1445. Accessed April 22, 2016.

21. Charles AM, Campbell-Stennett D, Yatich N, Jolly PE. Predictors of anemia among pregnant women in Westmoreland, Jamaica. Health Care Women Int. 2010;31(7):585-598.

22. World Health Organization. WHO Global Database on Anaemia: Jamaica. Geneva, Switzerland; 2006. Available from: http://who.int/ vmnis/anaemia/data/database/countries/jam_ida.pdf?ua=1. Accessed April 9, 2017.

23. Planning Institute of Jamaica, Kingston, Jamaica. Available from: http://www.pioj.gov.jm/Portals/0/Sustainable_Development/PovertyEnvironmenta1\%20Vulnerability\%20Relationship.pdf. Accessed May 18, 2017.
24. Planning Institute of Jamaica, Kingston, Jamaica. Available from: http://www.pioj.gov.jm/Portals/0/Social_Sector/Executive\%20 Summary_JSLC\%202012.pdf. Accessed May 18, 2017.

25. Luo ZC, Wilkins R, Kramer MS. Effect of Neighborhood income and maternal education on birth outcomes: a population-based study. Can Med Assoc J. 2006;174(10):1415-1420.

26. Andersen AMN, Mortensen LH. Socioeconomic inequality in birth outcomes: what do the indicators tell us, and where do we find the data? Can Med Assoc J. 2006;174(10):1429-1430.

27. Idowu OA, Mafiana CF, Sotiloye D. Anaemia in pregnancy: a survey of pregnant women in Abeokuta, Nigeria. Afr Health Sci. 2005; 5(4):295-299.

28. Alemu T, Umeta M. Reproductive and obstetric factors are key predictors of maternal anemia during pregnancy in Ethiopia: evidence from demographic and health survey. Anemia. 2015:1-8.

29. Zhang Q, Li Z, Ananth CV. Prevalence and risk factors for anaemia in pregnant women: a population-based prospective cohort study in China. Paediatr Perinat Epidemiol. 2009;23(4):282-291.

30. Dainty JR, Berry R, Lynch SR, Harvey LJ, Fairweather-Tait SJ. Estimation of dietary iron bioavailability from food iron intake and iron status. PLoS One. 2014;9(10):e111824.

31. Jersey SJ, Nicholson JM, Callaway LK, Daniels LA. A prospective study of pregnancy weight gain in Australian women. Aust NZJ Obstet Gynaecol. 2012;52(6):545-551.

32. The World Bank [webpage on the Internet]. Jamaica Overview; 2017. Available from: http://www.worldbank.org/en/country/jamaica/ overview. Accessed April 9, 2017.

33. Pan American Health Organization [webpage on the Internet]. Health in the Americas: Jamaica; 2012. Available from: http:// www.paho.org/salud-en-las-americas-2012/index.php?option=com docman\&task=doc_view\&gid=136\&Itemid=. Accessed April 9, 2017.

34. Statistical Institute of Jamaica, Kingston, Jamaica. Available from: http://www.pioj.gov.jm/Portals/0/Social_Sector/OVERVIEW\%20 JSLC\%202009\%20FINAL.pdf. Accessed May 18, 2017.

35. Farid Z, Patwardhan VN, Darby WJ. Parasitism and anemia. Am J Clin Nutr. 1969;22(5):498-503.

36. Ndomugyenyi R, Kabatereine N, Olsen A, Magnusses P. Malaria and hookworm infections in relation to haemoglobin and serum ferritin levels in pregnancy in Masindi district, Western Uganda. Trans $R$ Soc Trop Med Hyg. 2002;102(2):130-136.

37. Gyorkos TW, Gilbert NL, Larocque R, Casapía M, Montresor A. Re-visiting Trichuris trichiura intensity thresholds based on anemia during pregnancy. PLoS Negl Trop Dis. 2012;6(9):e1783.

38. Ramdath DD, Simeon DT, Wong MS, Grantham-McGregor SM. Iron status of schoolchildren with varying intensities of Trichuris trichiura infection. Parasitology. 1995;110(pt 3):347-351.

39. Stephenson LS, Holland CV, Cooper ES. The public health significance of Trichuris trichiura. Parasitology. 2000;121(suppl): S73-S95.

40. Da Silva BR, Brooker S, Hotex PJ, Montressor A, Engels D, Savioli L. Soil-transmitted helminth infections: updating the global picture. Trends Parasitol. 2003;19(12):547-551

41. Osazuwa F, Ayo OM, Imade P. A significant association between intestinal helminth infection and anaemia burden in children in rural communities of Edo State, Nigeria. North Am J Med Sci. 2011;3(1): 30-34.

42. García-Leiva J, Barreto-Zuñiga R, Estradas J, Torre A. Ascaris lumbricoides and iron deficiency anemia. Am J Gastroenterol. 2008;103(4): 1051-1052.

43. De Vizia B, Poggi V, Conenna R, Fiorillo A, Scippa L. Iron absorption and iron deficiency in infants and children with gastrointestinal diseases. J Pediatr Gastroenterol Nutr. 1992;14(1):21-26.

44. De Vizia B, Poggi V, Vajro P, Cucchiara S, Acampora A. Iron malabsorption in giardiasis. J Pediatr. 1985;107(1):75-78. 
45. Monajemzadeh SM, Monajemzadeh M. Comparison of iron and hematological indices in Giardia lamblia infection before and after treatment in 102 children in Ahwaz, Iran. Med Sci Monit. 2008;14(1): CR19-CR23.

46. Fong Ha J, Longnecker N. Doctor-patient communication: a review. Ochsner J. 2010;10:38-43.
47. Institute for Healthcare Communication [webpage on the Internet] [Impact of Communication in Healthcare]. Available from: http:// healthcarecomm.org/about-us/impact-of-communication-in-healthcare/. Accessed April 22, 2016.

International Journal of Women's Health

\section{Publish your work in this journal}

The International Journal of Women's Health is an international, peerreviewed open-access journal publishing original research, reports, editorials, reviews and commentaries on all aspects of women's healthcare including gynecology, obstetrics, and breast cancer. The manuscript management system is completely online and includes a very quick and fair peer-review system, which is all easy to use. Visit http://www.dovepress.com/testimonials.php to read real quotes from published authors.

Submit your manuscript here: http://www.dovepress.com/international-journal-of-womens-health-journal 